\title{
Effects of the interplay between organizational and national cultures in an international university-industry collaboration for technology innovation and transfer
}

\author{
Kumju Hwang ${ }^{1^{*}}$ \\ ${ }^{1}$ Department of Business Administration, Chung-Ang University \\ 기술혁신과 기술이전을 위한 국제산학협력에서 조직문화와 \\ 국가문화 간의 상호작용 효과 \\ 황금주 ${ }^{*}$ \\ ${ }^{1}$ 중앙대학교 상경학부
}

\begin{abstract}
The purpose of the study was to understand how the interplay between organizational and national cultures affects the management of IUICs (International University-Industry Collaboration) devoted to technology innovation and transfer. This study presents two examples of IUIC drawn from a qualitative research method, both involving a British university and a Japanese company. The first case illustrates how different organizational practices (organizational culture), which are nested in the national culture (values), raise questions about the role of ethical boundaries in causing misunderstandings and the deterioration of UIC relationships. The second case demonstrates how long-term relationships and extensive interpersonal interactions can play a positive role in IUIC. Practical implications, the limitation of this study and further studies have been discussed.

요 약 본 논문은 조직문화와 국가문화 간의 상호작용이 기술혁신과 기술이전을 위한 국제산학협력에 미치는 영향 을 분석하였다. 본 논문은 질적 연구를 통해 영국대학과 일본기업들 간의 국제산학협력에 관한 두 가지 사례를 제시 했다. 첫 번째 사례는 서로 다른 국가문화에 기반 한 가치가 특정한 조직행위를 형성했을 경우 윤리적 경계에 대한 문제가 발생하고 이는 오해를 초래하여 협력 당사자 간의 관계를 악화시킨다는 것을 보여 주었다. 두 번째 사례는 장 기적인 관계와 인적교환프로그램을 통한 협력당사자 간의 심도 깊은 상호작용이 국제산학협력에 긍정적인 역할을 한 다는 점을 보여주었다. 또한 본 논문은 실무적 함의와 이 연구의 한계점, 향후 연구에 대해 논의하였다.
\end{abstract}

Key Words : International University-Industry Collaboration, Interplay Between Organizational and National Cultures, Organizational Practice

\section{Introduction}

As noted by Etzkowitz and Leydesdorff[1], research-oriented academic institutions and commercially intensive industries, which were previously considered as functionally distinct, tend to be integrated at various levels (p.4). In fact, there is a growing trend toward university-industry collaboration (UIC) for technology innovation and transfer[2,3,4,5]. Hench[6] explains that the increased competition in the technology-driven market compels industry to embrace external resources to cope with expensive technology, as well with the reduction in the time needed for technological development due to the short lifespan of contemporary technology. Additionally, companies are burdened by the need to acquire specialized knowledge and to access global intelligence.

"Corresponding Author : Kumju Hwang(kumju@chonnam.ac.kr)

Received May 4, $2010 \quad$ Revised (1st June 2, 2010, 2nd August 31, 2010)

Accepted September 8, 2010 
They also must acquire important new techno-economic assets because they are required for international competition; it is too expensive for individual firms to replicate these assets entirely in-house[7]. As for academia, cuts in government funding have forced universities to find other financial sources and collaborate with the industries that fund their research[1,8]. Accordingly, collaboration between academia and industry is proliferating. Another example is innovation, which occurs internationally through multinational collaboration and cooperative arrangements between firms and universities[1,9].

UIC for technology innovation and transfer across national boundaries has been accelerated by the intense international competition in the high-technology market. However, few studies have focused on managing research programs and groups[10]. This is also the case for cross-cultural and organizational factors[2] affecting UIC, as well as the successful management of general university-industry alliances[3]. Equally rare is research into the cross-cultural and inter-organizational issues that arise in international university-industry collaborations (IUICs) established for technology innovation and transfer.

In this paper, I describe a study aimed at examining the organizational factors and multi-cultural issues that come into play when academia and industry collaborate internationally to produce or transfer technologies.

\section{Literature review}

Academics have agreed on two new forms of knowledge production growing out of cross-disciplinary collaborations between industry and universities. One is called the "triple helix"[11] and the other is called "mode 2 "[12,13]. Recent research has shown that collaboration between universities and industry R\&D is particularly productive[2,14-16]. However, managing such collaborations is complicated and challenging.

Most studies on collaboration have sought to explain it from the perspectives of business management and policy-making in science and technology. The researchers have attempted to estimate the extent to which collaboration can help or hinder businesses by producing and transferring scientific and technical knowledge, as well as by managing intellectual property [17-20]. However, they have limited themselves primarily to studying intellectual knowledge as an economic commodity and collaboration as a managerial tool. They have not really dealt with the management of research, ignoring issues such as organizational effects and leadership[21]. To the extent previous research has addressed research management it has adopted a macro perspective involving, for example, the funding of university research[22], policy making[2], and UIC generally[23-25]. Literature review on R\&D and collaboration shows the lack of micro level research management, such as organizational culture and leadership.

Geisler[26] suggests that the university-industry partnership can be understood within the framework of inter-organizational associations. Accordingly, IUIC can be characterized as cross-cultural and inter-organizational collaboration. Many approaches have been adopted to study cross-cultural organizational behavior and cross-cultural values[27-30] the topic is not new. The field of international business, in particular, has produced important and well-known contributions, including Hofstede's [31-33] cultural values frameworks, Hall's[34] high-context and low-context cultures, and Trompenaars and Hampden-Turner's[35] seven-dimension model of culture. Hofstede's frameworks have dominated cross-cultural research for about two decades, and Tsui[36] argues that "the field of cross-cultural research is now rich with many other cultural frameworks (e.g., Triandis, Schwartz, Singelis, Trompenaars)." Other studies indicate that UIC can lead to misunderstandings if the cultures of the collaborators are fundamentally different in their views of time, their use of language, their assumptions, goals, management styles, decision-making tendencies, and concepts of leadership, and so forth[3,4,37-39].

Although some authors treat national culture and organizational culture as separate constructs, "it is generally accepted that organizational culture is nested in national culture"[40], Understanding the interplay between organizational and national culture $[41,42]$ can be helpful in studying IUIC. Some authors characterize this interplay as convergent: convergence perspective[41, 43,44,45], 
whereas others characterize it as divergent: divergence perspective[46,47]. According to the divergence hypothesis, national culture shapes organizational culture. On the other hand, the convergence hypothesis insists that national culture does not constrain people's behavior[42] For this study, I adopted the divergence hypothesis.

Hofstede[48] notes that organizational culture is based on organizational practices, contexts, and factors, whereas national culture is based on values. Pothukuchi[40] argue that "national culture should be operationalized in terms of its values and organizational culture in terms of its core organizational practices" (p. 244).

Franke and Nadler[49] point out that values influence perceptions of right and wrong, so that morals, laws, and ethics are central components of many definitions of culture (p. 256). Ethical decision-making incorporates cultural effects[50-52], and ethical boundaries can be regarded as one of key components of organizational culture nested in national culture based on values. Indeed, there are two opposite views on professional codes of ethics in line with national culture. The 'etic' approach (convergence perspective) to ethics, influenced by Elder[53] who maintains that certain attitudes, beliefs and behaviors are 'culture free'[54,55], emphasizes the ethical commonality of professionals in the same field. On the contrary, the "emic"[54,56-58] approach (divergence perspective) to ethics views culture-specific factors shape professional codes of ethics[54,56-58].

There is a clear lack of research investigating micro-level management[2], organizational factors[3,26], and the cross-cultural aspects of IUIC. In my study, I attempted to understand the interplay between organizational and national culture by addressing how values, as a representation of the national culture, influence organizational practices, as a representation of the organizational culture. Accordingly, this study proposes a research hypothesis: The interplay between organizational and national culture may cause management conflicts between collaboration partners in terms of organizational practices based on values and ethical conduct. The study was meant to be preliminary and exploratory. I examined actual examples of IUIC to identify the issues that arise from the interplay between organizational and national culture. Specifically, I focused on cross-cultural and inter-organizational interactions to see what they can tell us about how the interplay between national and organizational culture affects the management of collaboration in IUICs devoted to technology innovation and transfer.

\section{Research methods}

\subsection{The interview as a research method}

I did not attempt to test my ideas statistically, and adopted instead a qualitative approach based on interview data. Interviews provide discursive data[59] that reflect dynamic interactions between parties. Interviews can be an appropriate method for studying cross-cultural and inter-organizational problems in collaborations. The data they provide can answer questions such as how cross-cultural aspects shape ethical boundaries and organizational practices. Interviews are particularly well suited for collecting data on inter-organizational practices in a cross-cultural context, because they capture the participants' direct experiences, including what they perceive, what situations they have been in, and how they feel about their interactions with their collaborators.

The questionnaire used for the interviews is based on the following theoretical approaches discussed in the preceding literature review, and the research hypothesis could be:

As British and Japanese UIC can be characterized as cross-cultural and inter-organizational collaboration, the interplay between organizational and national culture may cause management conflicts between collaboration partners in terms of organizational practices based on values and ethical conduct.

For investigating this research theme, I conducted in-depth interviews and used critical-incident techniques[60]. Each interview took between 60 and 90 minutes. The interviews were designed in three parts. In the first phase, in line with critical incident techniques[60] interviewees were asked to supply some examples of recent collaboration cases, and particularly focus on IUICs. In the second phase of the interview, participants were asked to describe in detail their interactions with their collaboration partners, management and processes that they had identified in phase one. In this stage, I 
asked them to concentrate on collaboration with Japanese firms. In the final phase of the interview, I encouraged participants to tell me about their collaboration management problems, cross-cultural misperception and misunderstandings, and difficulties in interacting with their Japanese partners. In this stage, I explicitly instigated discussion about the interplay between cross-cultural and inter-organizational effects on their collaboration if these had not come up in the course of the interview.

The interview data analysis was conducted in accordance with the framework of thematic analysis comprising three components: data reduction, data display and drawing conclusions[61]. The data were analyzed as narratives. As noted above, the analyses were also exploratory. For example, I did not conduct a formal content analysis by quantifying how frequently a certain word was used to assess the participant's emotional stability. Accordingly, the result in the next section will show the selection of underlying factors through manual highlighting of interview data according to the research theme, and the analysis involved more focused concepts to which I manually narrowed down from broad categories.

\subsection{Interviewees}

This study conducted interviews with four members of Imperial College, University of London academic staff who have extensive experience of international collaboration with Japanese companies. Having an international reputation of research excellence in science and technology, Imperial College is a place where wide-ranging collaboration takes place nationally and internationally. It should be noted that recruiting interviewees working for high-technology industry is quite difficult, because they are very sensitive to leaking technology information and organizational reputation. Accordingly, it is much more realistic approach to interviewing academics with experiences of industrial collaboration.

Professor Bearman is a top-ranked academic and core figure in the field of Materials and Aeronautics, and provides an experience of international collaboration with Honda corporation. With respect to Dr. Colclough's position in this group; he has responsibility over coordinate consortiums between the Centre of Process Systems Engineering and companies, and he does not teach or do research. His main responsibility is related to stretching the Centre's academic research into industrial application. Dr. Colclough, Dr. Adjiman and Dr. Asprey are working in the same research Centre: Process Systems Engineering. Dr. Adjiman and Dr. Asprey are engaged in a research collaboration with a Japanese chemical company. However, their projects are separate and they work with different collaborators within the Japanese company. As international collaboration between East and West can provide useful insights into how cross-cultural factors affect management in collaboration, this case study can tackle some interesting aspects of international collaboration.

\subsection{The collaborations sample}

International collaboration has features that are predetermined by international factors. These features include physical distance, differences in language, and barriers created by the interface between national and organizational cultures. For British-American collaborations, physical distance is a major problem, but cultural and language barriers are relatively low. A British-American collaboration is different from a British-Japanese collaboration, because cultural and language differences come into play in the latter. Generalizations cannot be made unless one can identify underlying contexts of collaboration. This consideration led me to restrict this study to a single type of collaboration, British-Japanese. The two specific collaborations show similarities and differences in their collaboration environments as follows:

1. Collaboration between the Centre of Process Systems Engineering at Imperial College, University of London, and a major Japanese company: The center wanted keep the Japanese company name anonymous. (Drs. Adjiman, Asprey, and Colclough). This collaboration was classified as cross-cultural, cross-linguistic, inter-organizational, remote-site, project-based, and UIC.

2. Collaboration between the Centre of Process Systems Engineering at Imperial College, University of London, and the major Japanese automaker Honda (Professor Bearman). This 
collaboration, which was quite long-term (twenty years), was classified as having cross-cultural and cross-linguistic elements. It was also classified as both remote-site and adjacent, because Honda sent a principal contact person from Japan to the Imperial College for three years.

\section{Results}

The data presented in this section concern cross-cultural and inter-organizational issues in the two IUIC cases, as well as the problems resulting from the interface between national and organizational cultures and geographical distances in these cases.

\subsection{University of London and a Japanese Company}

Dr. Adjiman was not able to distinguish between national cultural differences and cultural differences between industry and universities because she lacked long-term, intensive interactions with her collaborators. The fact that her main collaborator was a Czech national working for the Japanese company fortifies this point. People involved in long-distance collaboration with limited face-to-face communication may not detect important cultural differences. Additionally, most multinational corporations (including this Japanese company) have employees from various countries, so one cannot assume that the only cultures involved are Japanese and British. Accordingly, the influence of national culture on multinational companies may not be fully detected, making organizational culture an issue for future research.

On the other hand, Dr. Colclough was able to report that there were great cultural differences in the collaboration, and these differences led to difficulties in communication. He begins:

"With the Japanese, the culture is different. The cultural differences we have found were like a different world. After five years of working with the Japanese company it is still often quite difficult to understand how they work, why they don't respond more quickly, what they mean and what the hidden statements are behind what they say. Additionally you have to be very patient". When high-context culture (Japanese) collaborators and low-context culture (British) ones work together, they may be aware of this well-known cross-cultural difference showing that high-context cultural people prefer indirect communication depending on contexts and implications rather than denotative words[62]. However actual application and adopted strategy based on this cultural classification cannot be easy, because people from low-context cultures cannot understand levels and dimensions of indirectness and implications without very extensive experiences.

Dr. Colclough continues:

And quite often Dr. $\mathrm{X}$ says after a meeting, the thing has been fine and good. You thought you had a good meeting but several people came into my office and sat down and said it was terrible. I said: "Why is it terrible?"Then he explained all the problems and difficulties, which were not solved in the meetings. All the meetings seemed to have gone very well. Because in general, they will not turn around and say that no, that is not what they want, or no, that is not the way we need to do things. Instead they will say: "We have these questions..."They are so incredibly polite that they prefer to come to me as an intermediary. They will tell me all the problems and I will go away and see the other people and say: "Look. This is the situation. This is what we need to do."There is a great tradition of a kind of intermediary. They have someone between companies and company links in Japan, someone who acts for both sides. So any impoliteness and any aggression is not shown to the other company, or your customer, but instead to your intermediary.

This is a remarkable example of a barrier caused by the interplay between organizational and national cultures that affects collaborative relationships and collaboration processes. It is also an archetypal example of how organizational culture embodies national culture and how the intermediary role of Japanese companies creates a misunderstanding for the British collaborators that has not have previous experiences of this kind of intermediary role. Dr. Colclough's report also documents the extremely politeness of the Japanese culture and their collectivist attitude toward work-related issues As Adler[63] explains, "Members of collectivist cultures place much 
importance on fitting in harmoniously and saving face. Determinism characterizes such collective cultures as the Japanese one, where people believe that the will of the group should determine members' beliefs and behavior" (pp. 47-48).

Dr. Colclough gives another very interesting example of intercultural organizational behavior from his experience with the Japanese company:

They always act with great integrity as far as we are concerned. They pushed the boundaries and it was strange enough that they asked us to help them with this sort of internal fighting and the managerial disputes within the Japanese company, because there is a level of status attached to having a relationship with us. They set it up and build up a set of relationships based on favors done. We are part of the tools that they use to generate favors for managers and head officers and someone else. It builds the personal status and when the internal fights take place about who is owning us and the relationship, we have been asked to say that we don't like that person and that he is not so confident. So they asked us to actually send a message to the Japanese company's board saying that we are not happy with a particular person involved in the internal power struggle. This proves to be very difficult, because we think this behavior is not ethical, not right to do. But within their ethical framework, it is quite acceptable. That's what your people do for you. We are Dr. M. and T.'s people and they asked us to do something about that, so do it. And then they would look after our interests in the company. So those sorts of things are difficult to understand and give us problems of responding. In fact, we did not do what they asked. What we can do is to say that we think you are extremely good people and that we are very happy to work with you and that we would worry if there was a change of personnel. So we said that and then I received quite a sharp letter saying that we betrayed them by not doing this. So there are cultural differences and some communication difficulties.

Adler[63] explains how universalism and particularism affect the business relationship. She says that universalistic cultures rely on comprehensive contracts to document the "rules"of the business relationship, whereas particularistic cultures maintain commitment using much looser written agreements and rely on the strength of their personal relationships. She goes on to say that joint ventures, strategic alliances, and business negotiations, which generally are between universalists and particularists, raise ethical questions from the perspectives of both cultures. Dr. Colclough's report notes that ethical questions arose about what one should or should not to do in particular circumstances. These questions illustrate how the universalists and the particularists difference in their organizational behavior. Thus, when international collaborations involve different cultures, a barrier can result from the interplay between the organizational and national cultures.

\subsection{University of London and Honda}

The most important difference between this case and the first one is the existence of a long-term relationship in the latter. Professor Bearman notes,

I first talked to Honda 20 years ago, so it is a very long relationship. This is perhaps peculiar to Japanese companies. The Japanese, I think, like to have these long relationships, because then lots of trust builds up between us and them. Also, the staff they have do not change very often. I mean they work with a company for life, so some of the people there now are the same people who were there 20 years ago. But in a UK company it may be completely different people, so it is difficult to have such a long-term relationship.

Professor Bearman's report indicates that the organizational culture, which is intertwined with the national culture, formed a long-term collaborative relationship that has helped build a high level of trust level and minimizes cross-cultural problems. The relationship cuts across cultural boundaries, making the management of collaboration and communication easier.

Before use of e-mail became widespread, Honda actually sent a researcher to Imperial College for three years to work with people in the Aeronautics department (an example of personnel exchange). Like the positive contribution of expatriates[62,64] to cross-cultural communication, the personnel exchange in this case provided a useful tool for overcoming cross-cultural barriers by serving as a mediator between the two parties. The use of personnel exchange is a useful way to remove the cultural and language barriers and to solve the problems resulting from geographical remoteness. E-mail, 
even though it is a revolutionary channel that facilitates communication between remote sites, cannot solve the problems of language and cultural barriers.

In the present case, the long-term relationship led to a more desirable collaboration process, which in turn generated trust. The tendency for Japanese employees and employers to commit themselves to work for the company for life enables them to have these long-term relationships.

\section{Conclusions and Discussions}

\subsection{Conclusion}

This study presents two examples of IUIC, both involving a British university and a Japanese company. The purpose of the study was to understand how the interplay between organizational and national cultures affects the management of IUIC. The first case illustrates how different organizational practices (organizational culture), which are nested in the national culture (values), raise questions about the role of ethical boundaries in causing misunderstandings and the deterioration of UIC relationships. The second case demonstrates how long-term relationship sand extensive interpersonal interactions can play a positive role in IUIC.

Cross-cultural skills include cross-cultural competence, social empathy, knowledge of the host culture, language competence, adaptation skills, and social integration[65,66]. The Honda case shows that sending a person overseas to an organization of the collaborating partner for an extended period of time can create a long-term relationship and thus develop cross-cultural competency in both parties. In addition, as illustrated by the role of Dr. Colclough, someone serving as an intermediary between collaborating organizations can be effective in helping representatives of a low-context culture cope with representatives of a high-context culture that prefers indirect communication and places a premium on polite manners.

The interviews revealed that long-term relationships that provide both parties extensive and direct experience of each other and establish trust can be of critical importance to the development of the cross-cultural skills necessary for successfully managing international collaboration. Tone et al.[62] argue that contemporary managers are challenged to create new management systems and organizations more suitable for the present business environment than the ones currently in place. It is important to note that the more one knows about others, the more accurately one can predict their behavior. The most important function of long-term relationships is building trust[67]. When such trust exists, information exchanges increase and collaborative communication improves[68,69,70].

The interview data suggest that the national barrier operates within an organizational system. Ethical boundaries and organizational behavior norms are closely related to one's cultural orientation. When one party misperceives the other party's ethical boundaries and applies its own ethical boundaries to the other party, misunderstandings about the relationship are inevitable. When Japanese collaborators asked Dr. Colclough's Centre to do them a favor, a misperception of each other's ethical boundaries arose. From the Japanese collaborators' point of view, asking for a favor in the context of an organizational power struggle is an acceptable organizational practice. However, the British collaborators do not look at the request as an ethical practice, and the Centre refused to grant the favor to the Japanese collaborators. The Japanese collaborators raised a question about their relationship with the Centre and condemned it. This anecdote illustrates how the interplay between organizational culture (represented by organizational practices) and national culture (represented by values) can challenge collaborative relationships between organizations. The deterioration of the relationship cannot easily be explained by national cultural barriers or inter-organizational differences. The barrier between international collaborators has meaning within the context of an intercultural organizational approach. This implies that culture permeates every aspect of behavior in every organization, and supports the divergence perspective explained in the literature review.

Adler[63] maintains that Laurent's[71] work-related behavior and belief systems, and Hofstede's[31] five dimensions (individualism/collectivism, power distance, uncertainty avoidance, career success/quality of life, and Confucian dynamism) highlight the most important 
cultural differences affecting organizations. For example, having someone play the role of an intermediary is a unique organizational practice influenced by a given culture, say Japanese. More generally, the national culture influences the organizational barriers represented by dissimilarities in decision-making processes and the organizational structures with respect to hierarchy, communication patterns, and informal relationships. My results suggest that "barriers caused by an interplay between national and organizational culture" is a more appropriate category than "cultural barriers" for analyzing international collaboration.

\subsection{Practical Implications}

The results of this study allow me to offer practical recommendations for the management of IUIC. First, the collaborators should be provided with extensive direct experiences of each other so that a long-term relationship and trust can be established. Long-term relationship (link duration) can refer to the point that the two partners have been doing collaboration continuously for a given period of time[69]. Although it is very difficult to generalize an operational definition of long-term relationship[72], I can initially suggest 4 to 5 years as 'honeymoon period' drawn from previous studies[69,72]. In the honeymoon period, collaborative partners build up goodwill and trust, and start having confidence in mutual benefits from their collaboration. Accordingly, long-term relationship should take much more than five years.

Second, someone needs to fill the role of intermediary. As Kodama[73] says, "I regard the university-industry linkage intermediaries as entities that reduce search costs and bargaining costs for the firms and universities that are seeking collaboration partners. The search costs here refer to time and other resources necessary to search for potential collaboration partners. The bargaining costs are those associated with negotiation and coordination with potential partners" (p.1226). The IUIC intermediary should be expected to anticipate cross-cultural and inter-organizational barriers and help the collaborators overcome them. This means that the intermediary's role should be expanded to provide practical assistance to management of the IUIC. This expansion becomes more important the greater the proliferation of IUICs. Accordingly, intermediaries such as the technology transfer officers in universities and company R\&D managers need training in cross-cultural and inter-organizational management guided by extensive cross-cultural and inter-organizational experiences. Human resource exchange programs between companies and strategically important universities (Ph.D. or post-doctoral programs) are potentially a good tool for developing competence in intermediaries. Studies on UIC suggest that personnel exchange programs usually take two forms. One is that firms send their employees to their partner universities[74]. In this case, the employees usually work as postgraduate students or post-doctoral researchers in the universities. The other is that universities send their students or researchers to corporate laboratories as researchers, which usually takes relatively short-term (3-6 months or less) technology transfer[74,75].

High competition has also compelled Korean firms and universities to find international partners for technological innovation and transfer. They have played a role of both technology transferors and transferees. As overseas companies support more R\&D research fund per a single project than domestic companies, studies suggest that Korean universities should seek more overseas corporate partners[76,77]. In line with the increasing IUIC, Korean universities or firms which plan and implement IUIC should build up practical tools to overcome cross-cultural and inter-organizational barriers.

\subsection{Limitation and Further study}

Despite its positive contributions, my study has the limitation that the anecdotes are not particularly rich and are based on a relatively small number of interviews. However, it should be kept in mind that the study was intended only as a preliminary exploration. As such, this study can be understood as a case of how the interplay between organizational and national cultures affects the management of IUICs between a British university and Japanese companies rather than the generalization for the divergent perspective in general IUIC.

Further research is needed to better understand the issues addressed in this study, such as organizational structures, leadership, interpersonal interactions, zones of interaction, communication systems, ethical boundaries, and decision-making processes based on inter-organizational models. These issues should be 
explored systematically to provide a foundation for quantitative studies with sufficiently large samples to adequately represent various research settings. Additionally, further studies are needed to provide a foundation for the creation of IUIC assistance programs aimed at overcoming the barriers caused by inter-organizational factors and problems with the interplay between organizational and national cultures.

\section{References}

[1] H. Etzkowitz, and L. Leydesdorff, Universities and the global knowledge economy: a triple helix of university-industry-government relations, Printer, London and Washington, 1997.

[2] E. Adler, and M. Flemming, "The challenge of managing boundary-spanning research activities", Experiences from the Swedish Context, Vol. 38, No. 7, pp. 1136-1149, 2009.

[3] M. R. Cyert, and S. P. Goodman, "Creating effective university-industry alliances: an organizational learning perspective", Organizational Dynamics, Vol. 25, No. 4, pp. 45-57, 1997.

[4] 김종진 최종인, “산학협력 : 대학의 새로운 역할”, 한국 산학기술학회논문지, Vol. 6, No. 6, pp. 461-467, 2005.

[5] 송건호, 이철규, 유왕진, 이동명, “산학협력이 중소벤처 기업의 기술혁신성과에 미치는 영향에 대한 연구", 한 국산학기술학회논문지, Vol. 10, No. 11, pp. 3340-3353, 2009.

[6] L. L. Hench, From concept to commerce: the challenge of technology transfer in materials, MRS Bulletin, pp. 49-53, August, 1990.

[7] F. X. Gibbons, M. Heiweg-Larsen, and M. Gerrard, "Prevalence estimates and adolescent risk behavior: cross-cultural differences in social influence", Journal of Applied Psychology, Vol. 80, No. 1, pp. 107-121, 1995.

[8] I. Mackenzie, and R. Jones, University and industry: new opportunities from collaboration with UK universities and polytechnics, The Economist Publications Ltd, London, 1985.

[9] D. M. Waguespack, and J. K. Birnir, "Foreignness and the diffusion of ideas", Journal of Engineering \&Technology Management, Vol. 22, No. 12, pp. 31-50, March-Jun, 2005.

[10] E. Erno-Kjolhede, Managing collaborative research: unveiling the micro dynamics of the triple helix,
Copenhagen School Press, Copenhagen, 2001.

[11] H. Etzkowitz, and L. Leydesdorff, "The dynamics of innovation: from national systems and 'mode 2' to a triple helix of university. industry. government relations", Research Policy, Vol. 29, No. 2, pp. 109-123, 2000.

[12] M. Gibbons, L. Camile, H. Nowotny, S. Schwartsman, P. Scott, and M. Trow, The new production of knowledge, SAGE Publications ltd, London, 1994.

[13] H. Nowotny, P. Scott, and M. Gibbons, Re-thinking science: knowledge and the public in an age of uncertainty, Polity Press, Cambridge, 2001.

[14] E. Arnold, N. Brown, A. Eriksson, T. Jansson, A. Muscio, J. Nahlinder, and R. Zaman, The role of industrial research institutes in the national innovation system, Vinnova Publication, 2007.

[15] T. Dolk, and A. Sandström, National and regional cluster profiles, Vinnova Publication, 2007.

[16] L. Norgren, R. Nilsson, E. Perez, A. P. Sandstrom, and P. Sandgren, Needs driven R\&D programmes in sectorial innovation systems, Vinnova Publication, 2007.

[17] H. Cameron, and C. L. Bas, "Knowledge dissemination, collaboration between agents and intellectual property: new evidence for science and technology policy", Economic Applique, Vol. 52, No. 2, pp. 237-266, 1999.

[18] S. Davenport, C. Grimes, and J. Davis, "Research collaboration and behavioral additionality: a New Zealand case study", Technology Analysis \& Strategic Management, Vol. 10, No. 1, pp. 55-67, 1998.

[19] S. Marjit, and A. Mukherjee, "Technology collaboration and foreign equity participation: a theoretical analysis", Review of international economics, Vol. 6, No. 1, pp. 142-150, 1998.

[20] N. S. Vonortas, "Rights and knowledge dissemination in research joint ventures", Science Communication, Vol. 19, No. 1, pp. 81-92, 1997.

[21] 서정하, 허용정, "국내대학의 산학협력단장의 리더십 에 관한 연구”, 한국산학기술학회논문지, Vol. 6, No. 2, pp. 172-177, 2005.

[22] A. Geuna, "The economics of knowledge production: funding and the structure of university research", In E. Cheltenham(ed), New Horizons in the Economics of Innovation, UK/Northampton, March, 1999.

[23] D. Gray, M. Lindblad, and J. Rudolph, "Industry. university research centers: a multivariate analysis of member retention", Journal of Technology Transfer, Vol. 26, No. 3, pp. 247-254, 2001. 
[24] Y. Lee, "The sustainability of university. industry research collaboration: an empirical assessment", Journal of Technology Transfer, Vol. 25, No. 2, pp. 111-133, 2000

[25] E. Starbuck, "Optimizing university research collaborations", Research Technology Management, Vol. 44, No. 1, pp. 40-45, 2001.

[26] E. Geisler, "Industry-university technology cooperation: a theory of inter-organizational relationships", Technology Analysis \&Strategic Management, Vol. 7, No. 2, pp. 217-229, Jun, 1995.

[27] D. S. Elenkov, and I. M. Manev, "Top management leadership and influence on innovation: the role of sociocultural context", Journal of Management, Vol. 31, No. 3, pp. 381-402, 2005.

[28] X. Huang, and E. V. Vliert, "Where intrinsic job satisfaction fails to work: national moderators of intrinsic motivation", Journal of Organizational Behavior, Vol. 24, No. 2, pp. 159-179, 2003.

[29] L. Huff, and L. Kelley, "Is collectivism a liability? the impact of culture on organizational trust and customer orientation: a seven-nation study", Journal of Business Research, Vol. 58, No. 1, pp. 96-102, 2005.

[30] P. E. Spector, C. L. Cooper, J. I. Sanchez, M. O’Driscoll, K. Sparks, P. Bernin, A. Bussing, P. Dewe, P. Hart, L. Lu, K. Miller, L. R. De Moraes, G. M. Ostrognay, M. Pagon, H. Pitariu, S. Poelmans, P. Radharishnan, V. Russinova, V. Salamatov, J. F. Salgado, S. Shima, O. L. Siu, J. B. Stora, M. Teichmann, T. Theorell, P. Vlerick, M. Westman, M. Widerszal-Bazyl, P. T. P. Wong, and S. Yu, "Locus of control and well-being at work: How generalizable are Western findings?", Academy of Management Journal, Vol. 45, No. 2, pp. 453-466, 2002.

[31] G. Hofstede, Cultures and organizations: intercultural cooperation and its importance for survival; software of the mind, Harper Collins Business, London, 1991.

[32] G. Hofstede, Culture's consequences: comparing values, behaviors, institutions, and organizations across nations, Sage, Thousand Oaks, 2001.

[33] G. Hofstede, "What did GLOBE really measure? researchers' minds versus respondents' minds", Journal of International Business Studies, Vol. 37, No. 6, pp. 882-896, 2006

[34] E. T. Hall, Beyond culture, Doubleday Anchor, New York, 1977

[35] C. Hampden-Turner, and F. Trompenaars, Riding the waves of culture: understanding diversity in global business, McGraw-Hill, New York, 1998.

[36] S. Anne, S. Tsui, S. Nifadkar, and Y. O. Amy, "Cross-national, cross-cultural organizational behavior research: advances, gaps, and recommendations", Journal of Management, Vol. 33, No. 3, pp. 426-478, 2010.

[37] M. C. Dorf, "Foreword: the limits of socratic deliberation", Harvard Law Review, Vol. 112, No. 1, pp. 4-83, November, 1998.

[38] E. Geisler, and A. H. Rubenstein, University-industry relations: a review of major issues, the industry-university-government relationship, pp. 43-64, 1989.

[39] E. Geisler, A. furino, and T. K. Kiresuk, "Factor in the success or failure of industry-university cooperative research centers", Interfaces, Vol. 20, No. 6, pp. 99-109, 1990.

[40] V. Pothukuchi, F. Damanpour, J. Choi, C. C. Chen, and S. Park, "National and organizational culture differences and international joint venture performance", Journal of International Business Studies, Vol. 33, No. 2, pp. 243-265, 2002.

[41] A. Dastmalchian, S. Lee, and I. Ng, "The interplay between organizational and national cultures: a comparison of organizational practices in Canada and South Korea using the competing values framework", International Journal of Human Resource Management, Vol. 11, No. 2, pp. $388-414,2000$.

[42] M. Naor, and L. Kevin, "The globalization of operations in Eastern and Western countries: unpacking the relationship between national and organizational culture and its impact on manufacturing performance," Journal of Operations Management, Vol. 28, No. 3, pp. 194-205, May, 2010.

[43] N. J. Adler, and M. Jelinek, "2Is 'organization culture' culture bound?", Human Resource Management, Vol. 25, No. 1, pp. 73-90, Spring, 1986.

[44] J. J. van Muijen, and P. L. Koopman, "The influence of national culture on organizational culture. a comparative study between 10 countries", European Work \& Organizational Psychologist, Vol. 4, No. 4, pp. 367-380, 1994.

[45] D. L. Shapiro, S. A. Furst, G. M. Spreitzer, and M. A. Von Glinow, "Transnational teams in the electronic age: are team identity and high performance at risk?", Journal of Organizational Behavior Special Issue, Vol. 23, No. 4, pp. 455-467, Jun, 2002.

[46] Z. Aycan, R. N. Kanungo, and J. B. P. Sinha, 
"Organizational culture and human resource management practices: the model of culture fit", Journal of Cross-Cultural Psychology, Vol. 30, No. 4, pp. 501 526, 1999.

[47] S. C. Schneider, "National vs. corporate culture: implications for human resource management", Human Resource Management, Vol. 27, No. 2, pp. $231-246$, 1988.

[48] G. Hofstede, "Problems remain, but theories will change: the universal and the specific in 21 st-century global management", Organizational Dynamics, Vol. 28, No. 1, pp. 34-44, Summer, 1999.

[49] G. R. Franke, and S. S. Nadler, "Culture, economic development, and national ethical attitudes", Journal of Business Research, Vol. 61, No. 3, pp. 254 - 264, 2008.

[50] O. C. Ferrell, L. G. Gresham, and J. Fraedrich, "A synthesis of ethical decision models for marketing", Journal of Macromarketing, Vol. 9, No. 2, pp. 55-64, 1989.

[51] S. D. Hunt, and S. J. Vitell, "The general theory of marketing ethics: a revision and three questions", Journal of Macromarketing, Vol, 26, No. 2, pp, 143 153, 2006.

[52] K. J. Srnka, "Culture's role in marketers' ethical decision making: an integrated theoretical framework", Academy of Marketing Science Review, Vol. 2004, No. 1, pp. 1 - 34, 2004.

[53] J. W. Elder, "Comparative cross-national methodology", Annual Review of Sociology, Vol. 2, No. 1, pp. 209-230, 1976.

[54] S. T. Jakubowski, P. Chao, S. K. Huh, and S. Maheshwari, "A cross-country comparison of the codes of professional conduct of certified/chartered accountants", Journal of Business Ethics, Vol. 35, No. 2, pp. $111-129,2002$.

[55] L. R. Smeltzer, and M. M. Jennings, "Why an international code of business ethics would be good for business", Journal of Business Ethics, Vol. 17, No. 1, pp. $57-66,1998$.

[56] H. C. Triandis, The analysis of subjective culture, Wiley, New York, 1972.

[57] E. T. Hall, Beyond culture, Doubleday, New York, 1976.

[58] E. T. Hall, "Learning the Arabs' silent language", Psychology Today, vol. 13, No. 3, pp. 45-53, 1979.

[59] J. A. Holstein, and J. F. Gubrium, "Active interviewing", in, D. Silverman(ed), Qualitative research: theory, method and practice, SAGE
Publications, London, 1997.

[60] M. Easterby-Smith, R. Thorpe, and A. Lowe, Management research - an introduction, 2nd edn. Sage, London, 2002.

[61] M. B. Miles, and A. M. Huberman, Qualitative data analysis: an expanded sourcebook, 2nd edn. Sage, London, 1994.

[62] K. Tone, M. Skitmore, and J. K. W. Wong, "An investigation of the impact of cross-cultural communication on the management of construction projects in Samoa", Construction Management \& Economics, Vol. 27, No. 4, pp. 343-361, April, 2009.

[63] N. J. Adler, International dimensions of organizational behavior, South-Western College Publishing, Ohio, 1997.

[64] R. L. Tung, "Managing cross-national and intra-national diversity", Human Resource Management, Vol. 32, No. 4, pp. 461 - 477, 1993.

[65] H. J. Leavitt, and H. Bahrami, Managerial psychology: managing behavior in organizations, University of Chicago Press, Chicago, 1988.

[66] M. V. Redmond, "Cultural distance as a mediating factor between stress and intercultural communication competence", International Journal of Intercultural Relations, Vol. 24, No. 1, pp. 151-159, 2000.

[67] M. Bensaou, and N. Venkatraman, "Configurations of inter organizational relationships: a comparison between U.S. and Japanese auto makers", Management Science, Vol. 41, No. 9, pp. 471 - 492, 1995.

[68] I. J. Chen, and A. Paulraj, "Towards a theory of supply chain management: the constructs and measurement", Journal of Operations Management, Vol. 22, No. 2, pp. 119 - 150, 2004.

[69] M. Kotabe, X. Martin, and H. Domoto, "Gaining from vertical partnerships: knowledge from vertical partnerships: knowledge Transfer, relationship duration and supplier performance improvement in the U.S. and Japanese automotive industries", Strategic Management Journal, Vol. 24, No. 4, pp. 293, April, 2003.

[70] J. J. Mohr, R. J. Fisher, and J. R. Nevin, "Collaborative communication in interfirm relationships: moderating effects of integration", Journal of Marketing, Vol. 60, No. 3, pp. 103-115, July, 1996.

[71] A. Laurent, "The cultural diversity of western conceptions of management", International Studies of Management and Organization, Vol. 13, No. 12, pp. 75-96, 1983.

[72] D. A. Levinthal, and M. Fichman, "Dynamics of 
interorganizational attachments: auditor-client relationships", Administrative Science Quarterly, Vol. 33, No. 3, pp. 345-369, 1988.

[73] S. Kodama, "Dynamic ferrofluid sculpture: organic shape-changing art forms", Communications of the $A C M$, Vol. 51, No. 6, pp. 79-81, Jun, 2008.

[74] C. Ann, and A. Seror, "A model of institutional network dynamics and a comparative case analysis of information technology transfer", The Journal of Technology Transfer, Vol. 23, No. 3, pp. 39-50, 1998.

[75] J. W. Amy, W. E. Baitinger, and R. G. Cooks, "Building mass spectrometers and a philosophy of research", Journal of the American Society for Mass Spectrometry, Vol. 1, No. 2, pp. 119-128, 1990.

[76] J. Yang, T. Lee, D. Han, S. Han, K. Kim, and D. Rue, A study on academic research and development activities in Korea in 2007, National Research Foundation of Korea, 2008.

[77] S. Han, S. Cho, J. Yang, and D. Rue, A study on academic research and development activities in Korea in 2008, National Research Foundation of Korea, 2009.

Kumju Hwang

[Regular member]

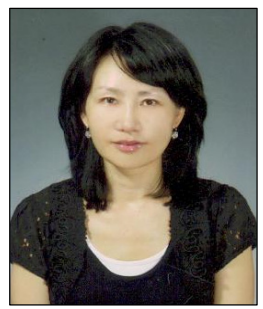

- Dec. 1998 : Reading Univ., Communication, MA

- April. 2003 : Imperial College, London Univ., Business Administration, $\mathrm{PhD}$

- Sep. $2007 \sim$ Aug. 2010 : Chonnam National Univ., Assistant Professor

- Sep. $2010 \sim$ current : Chung-Ang Univ., Dept. of Business Administration, Assistant Professor

$<$ Research Interests $>$

Technology Marketing, R\&D Management 